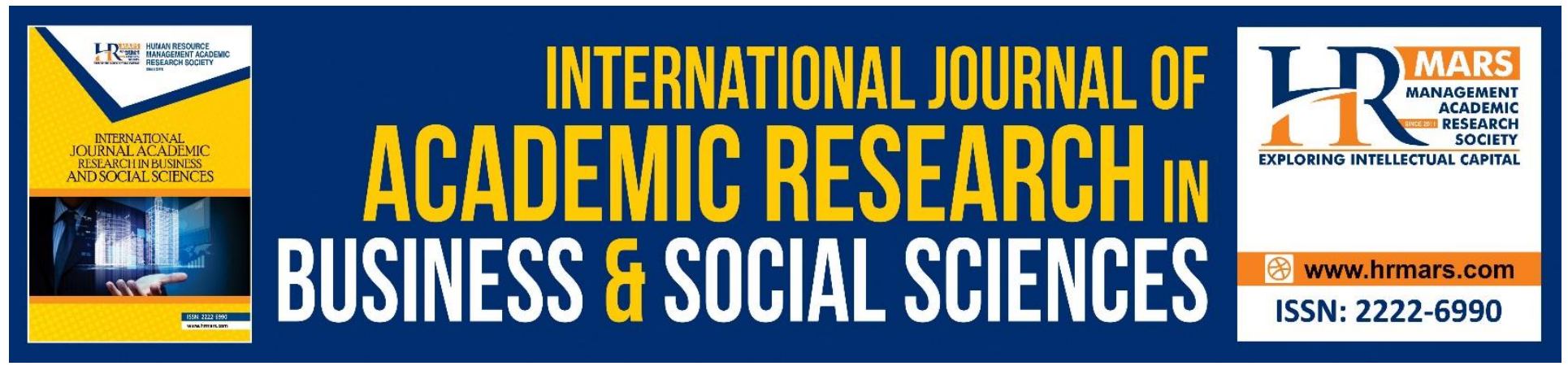

\title{
Prediction of Information Technology and Management Supports on Intention towards Paperless among Malaysian Public University Staff: A Pilot Study
}

Mohd Hamran Mohamad, Hasan Al-Banna Mohamed, Kamarulzaman Lamin, Norlaila Mazura Hj. Mohaiyadin \& Khairunnisa Mardzuki

To Link this Article: http://dx.doi.org/10.6007/IJARBSS/v8-i6/4308

DOI: $\quad 10.6007 /$ IJARBSS/v8-i6/4308

Received: 24 May 2018, Revised: 19 June 2018, Accepted: 29 June 2018

Published Online: 08 July 2018

In-Text Citation: (Mohamad, Mohamed, Lamin, Mohaiyadin, \& Mardzuki, 2018)

To Cite this Article: Mohamad, M. H., Mohamed, H. A.-B., Lamin, K., Mohaiyadin, N. M. H., \& Mardzuki, K. (2018). Prediction of Information Technology and Management Supports on Intention towards Paperless among Malaysian Public University Staff: A Pilot Study. International Journal of Academic Research in Business and Social Sciences, 8(6), 1144-1153.

Copyright: (c) 2018 The Author(s)

Published by Human Resource Management Academic Research Society (www.hrmars.com)

This article is published under the Creative Commons Attribution (CC BY 4.0) license. Anyone may reproduce, distribute, translate and create derivative works of this article (for both commercial and non-commercial purposes), subject to full attribution to the original publication and authors. The full terms of this license may be seen at: http://creativecommons.org/licences/by/4.0/legalcode

Vol. 8, No. 6, June 2018, Pg. 1144 - 1153

Full Terms \& Conditions of access and use can be found at http://hrmars.com/index.php/pages/detail/publication-ethics 


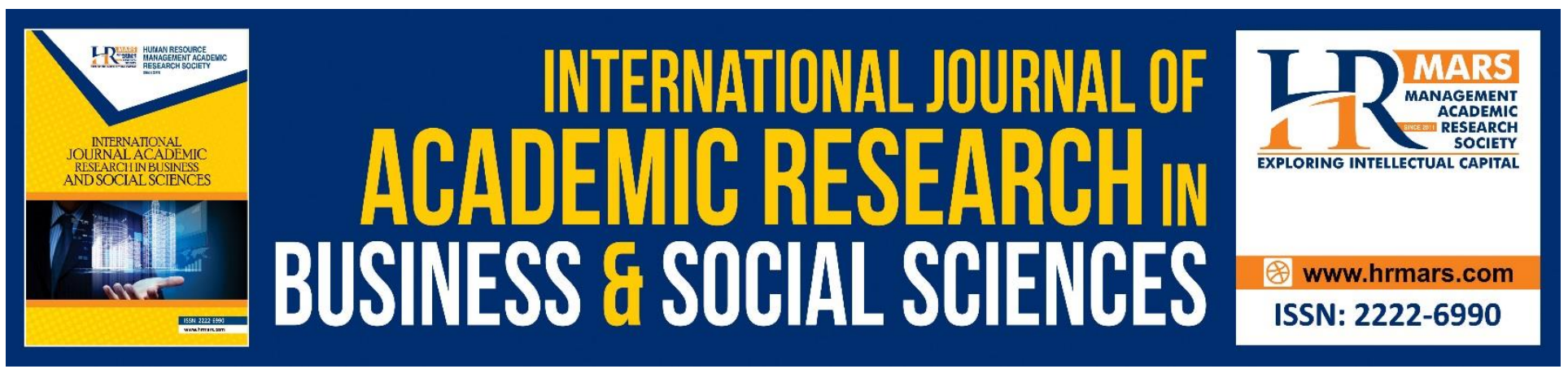

\title{
Prediction of Information Technology and Management Supports on Intention towards Paperless among Malaysian Public University Staff: A Pilot Study
}

\author{
Mohd Hamran Mohamad, Hasan Al-Banna Mohamed, \\ Kamarulzaman Lamin, Norlaila Mazura Hj. Mohaiyadin \& \\ Khairunnisa Mardzuki
}

Faculty of Defence Studies and Management, Universiti Pertahanan Nasional Malaysia, Sungai Besi

Camp, Kuala Lumpur, Malaysia

\begin{abstract}
Intention towards paperless become the heart of government transformation agenda through an electronic government program that is able to foster a sustainable environment at workplace. In human resource perspective, the desires of employees to practice paperless must be succeeded because they are the front-line operator to act for the effective and efficient work system that leads to organizational top performance. It is understood that recently, there are various issues reveal in the unsuccessful paperless process in organizations that depicts low intention towards paperless among the employees. Thus, organizations have to promote the intention towards paperless among their employees in order to improve their service delivery through proper paperless process. Information technology support and management support are revealed as possible determinants in influencing intention towards paperless among the employees. The purpose of this paper is to assess a small size of sample data on the IT support, management support and intention towards paperless in one of Malaysian public universities. Analysis on the content and face validity of the instrument leads to some improvement of the items used. As a result, reliability test of the instrument indicates all the constructs of the study are reliable (above 0.70) with high internal consistency of the items. Thus, the data for pilot study show evidence of reasonable regularity.
\end{abstract}

Keywords: Information Technology Support, Management Support, Intention Towards paperless, Malaysian Public University

Introduction

Malaysian public universities (UAs) have to excel their operations, especially in realizing the needs of government through the implementation of electronic government (e-government) (Saliza \& Kamil, 2012). E-government is important in today's government services sector because it promotes a green 
INTERNATIONAL JOURNAL OF ACADEMIC RESEARCH IN BUSINESS AND SOCIAL SCIENCES Vol. 8, No. 6, June 2018, E-ISSN: 2222-6990 @ 2018 HRMARS

environment for a sustainable development (Al-Khouri, 2013; Young, 2017). One of the mechanism how e-government leads green environment is the practice of paperless in daily operation by the civil servants (Al-Khouri, 2013; Government of Malaysia, 2011). Presently, paperless is important in attracting government confidence and trust on public universities and becomes the main factor for the saving of government expenses besides generating financial sustainability in the country (Manuel, Jesus, Maria \& Francisco, 2013). Thus, emphasizing on the acculturation of the paperless practice by each of the public university staff is of meaningful importance (Adzmi \& Mohd Yahya, 2013). This valuable culture drives the employees contributing towards the public universities better performances finally.

It has been revealed that faster transfer of data and information within the organization could be succeeded by the practice of paperless such as the use of e-filing (Anna \& Yusniza, 2010). It promotes an effective and efficient human capital who is able to perform the job to attain the organizational goal. Obviously, e-filing motivates individual employee for mutual benefits with other co-workers which he/she is responsible to share the information and data within the time needed. Another benefit of paperless such as the elimination of the use of large space for storage (Brusco, 2011) that leads to the cost elimination. Meaning that there is no financial burden of purchasing file cabinet furniture and providing additional rooms for traditional file and paper storage (Anna \& Yusniza, 2010). Importantly, the issues of high expenditure of paper usage and wastage of paper-based works in a UA working environment may be solved through the practice of paperless. By realizing the roles of paperless practice in succeeding the organization, hence, it is a must to earlier investigate how the paperless practice can be developed and promoted. However, the theory of reasoned action by Fishbean and Ajzen (1975) has emphasized that the behavioural intention is the foundation for the actual action taken by the individual and Davis (1989) furthermore, in his Technology Acceptance Model theory explains that the identification of determinants of the use of technology that lead to behavioral intention should be highly prioritized. Both theories are seen suitably can be applied in the context of paperless research. Thus, this study focuses on the intention towards paperless among the UA staff, which this can be realized by some potential determinant factors that exist in the UA currently.

Recently, research (Barker, Fiedler \& Johnson, 2008) has raised out the scenario about the university staff who are not desirable to fully use the technology facilities that give the benefits for paperless processes when performing their work activities. The reason being they may have less understanding, ability and confidence in the use of such technology or having small concern about the practice of paperless. As a result, they maintain to use traditional methods and approaches in operating their works. This finding should be given a serious concern if the similar scenario continuously exists in today's working environment at our UA. Another issue of paperless in UA which relates to a specific concern about how far the academicians in Malaysia are associated with technology development as implemented in e-journals and how much they intend and apply e-journals in taking the action to uphold the paperless process (Arzmi \& Mohd Yahya, 2013). This specific concern would be caused by the problem of low perceptions on the ease of use of technology and the usefulness of technology in applying e-journals among academicians. Basically, the features of those scenarios can actually influence the government's desire from its agencies as well as universities to uphold the transformation program towards electronic government (e-government) which is a foundation for successful government paperless (Azman, 2012). 
In the literature on e-government and paperless process mainly related to the service sector, researchers have examined that information technology (IT) support and management support are part of the significant predictors to promote the intention towards paperless (Mahmood et al., 2001; Obeidat, 2015; Thatcher et al., 2002). Therefore, based on the problems and importance of those three variables in the UA working environment, this study performs a study on the relationship between IT support, management support and intention towards paperless. Moreover, the contributions of IT support and management support to intention towards paperless still unclear since little study investigates on this relationship mainly when they involve those three variables as well as when it studies on the Malaysian UA perspective. However, for the first part of the evaluation, this paper desires to discuss a pilot test in the context of UA in the middle region of Malaysia. The aims of pilot test performed in this study are to examine the reliability of the instrument used. However, conducting content and face validity is also being considered to support the pilot test. Thus, the determination of the instrument is based on IT support and management support that represent independent variables and intention towards paperless as the dependent variable. This paper will be organized as follows; next a discussion of the methodology, then results of validity, reliability and frequency tests, and lastly conclusion is provided.

\section{Methodology}

Basically, this article focuses on a pilot test of the study as considered an earlier stage of research that involves small samples of UA staff. The sample was chosen based on the simple random sample. Usually, a few sample sizes selected for the pilot test which is about 15 to 30 respondents and can be added more when there are some cases happened from the test (Malhotra, 2010). Thus, this study distributed about a total of 30 copies of questionnaires to the UA staff in the middle region of Malaysia. From that, 23 were responded and received. Out of that, 3 were not completely filled in and so that, they are excluded from analysis.

According to Sekaran and Bougie (2016), the most practical measures are the analysis for the interitem uniformity reliability and the most familiar test is Cronbach's Alpha coefficient. Thus, this study conducted Cronbach's Alpha test to determine the coefficient value for the reliability of the items employed. The coefficient value basically explains the degree of internal consistency of the answered questions responded by the selected respondents within a certain period of times. The data were collected and analysed by using SPSS for windows. Importantly, before an analysis of reliability, this study initially conducted a content validity test by giving the draft of instrument to experts such as academicians and practitioners for their comments and corrections. Then, it was also forwarded to the distinctive respondents to ensure their understanding and capability in answering each of the questions. All the procedures until analysis work were completed within the periods of two months in January and February 2018.

\section{Instrumentation and Measurement of Variables}

This study used the questionnaire which gave the respondent the opportunity to make a choice for the answer. Basically, the items used in the questionnaire were measured based on respondents' perceptions. In accordance with such items, the Likert scale measurement technique is very suitable and reliable to be used in the questionnaire (Miller \& Salkind, 2002; Zainudin, 2010). It is understood that many social science research instruments use this technique as it provides the respondents with 
the opportunity to choose their choices freely and sincerely based on rational feelings. Therefore, this study determined the measurement of instrument involving all dependent and independent variables using the type of 5-point Likert scale. The advantages are these scales have many choices as well as preventing respondents to determine their answers based on improper cognitive loading (Churchill \& Peter, 1984; Cavana et al., 2001; Hair et al., 2013). Subsequently, in order to obtain meaningful results from the given feedback and the reliability of the scale most likely, the Likert 5point scale is well-known (Churchill \& Peter, 1984).

Furthermore, the 5-point scale is well employed as the respondents are able to demonstrate their best choice in addition, the scores can produce slightly higher mean scores than the highest possible score. Also, there will be very small differences between scale formats in terms of variation in mean (Dawes, 2008). More specifically, a 5-point scale uses a midpoint that can improve the quality of data obtained and reduce respondents' tendencies to make biased choices (Krosnick \& Fabrigar, 1997) since they are not forced to respond more positively or negatively. The middle point in a 5-point scale is very useful for respondents make a choice by choosing this point when they are uncertain. The choice for this midpoint is needed, especially when the topic of the question is highly sensitive.

Consequently, this study employed the variables of IT support, management support and intention towards paperless which they are single-dimensional based. Therefore, there are three parts of questions constructed in the questionnaire; for the section $B$, it is a set of nine questions that used to measure the perceived IT support and management support in influencing individual staff's intention towards paperless. Some of the questions used for IT support such as "a specific person (or group) is available for assistance with hardware and software difficulties" and "specialized instruction and training concerning software is available to me". Meanwhile, the example of management support questions used are "management is aware of the benefits that can be achieved with the use of technology" and "management always supports and encourages the use of technology for job related work". In section $\mathrm{C}$, it contains seven items that relate to the measurement of the intention towards paperless based on individual unit of analysis. Part of the items are "if a paperless system is installed at my university, I am willing to use it" and "I am looking forward to use a paperless system in the future". Before that, section A consists of questions that ask respondents' profiles. Basically, this study prioritized on the appropriate items in the survey in order to yield the accurate answers to the research questions and achieve the research objectives. Besides, for the survey, the reactive questionnaire was excluded because it gives a low response rate (Sekaran \& Bougie, 2016).

\section{Results Of Validity And Reliability Tests}

\section{Content and Face Validity}

This study conducted a content validity test to evaluate how far the relevancy and the representativeness of the elements within a measurement procedure will be used to measure a construct. It is consistent to Hair et al. (2013) and also Sekaran and Bougie (2016) explained that content validity is strongly required for the pre-test of the instruments that consists the activity of revisions, checking and judgements from respondents who have relevant character and/or group of specialists about the accuracy of the items selected to explain a right variable. In relation to that, this study has selected individual specialists from a well-known research university in Malaysia to assess 
INTERNATIONAL JOURNAL OF ACADEMIC RESEARCH IN BUSINESS AND SOCIAL SCIENCES Vol. 8, No. 6, June 2018, E-ISSN: 2222-6990 @ 2018 HRMARS

the distributed instrument. This is to ensure the items used are really appropriate and adequate to measure the constructs of the study. Besides, the checking also will make the items clearer to be understood by the respondents. Hence, some corrections and modifications of some items' words and sentence styles were performed. Basically, this study took about three weeks to finish the content and face validation tests. By having the correct content and face validity results, the trusted version of the instrument was able to be completely amended for the use in the next test of a pilot study.

\section{Reliability Test}

Reliability refers to whether or not the researcher is able to have the consistent answer by employing an instrument to measure something once and more. In easier terms, reliability is about how far the research method produces stable and consistent results (Gorondutse \& Haim, 2013). Thus, this study evaluated the internal consistency of the measurement procedure which was often performed by the previous researchers in testing the instrument reliability. Basically, the frequently value concerned for testing of reliability in validating the inter-item consistency is Cronbach's Alpha coefficient (Sekaran \& Bougie, 2016). Analysis of instrument reliability of this study by using SPSS for windows yielded the results with high values of Cronbach alpha coefficient ranging from 0.728 to 0.953 (See in the Table 1). These results were in-line with the rule of thumb that an instrument with a coefficient of 0.70 and more indicates a high reliability standard of measurement (Nunally, 2010; Hair et al., 2013; Sekaran \& Bougie, 2016). Actually, this study proved that measurement procedures used for the constructs have a similar high reliability level that yielded by the same measurement procedures of previous researches as utilized in Davis (1989), Venkatesh (2000), Venkatesh \& Davis (2000) and Obeidat (2015). Obviously, as mentioned by the above recognized scholars concerning the reliability level guideline, this study found that all the constructs are reliable.

Table 1. Reliability Test Using SPSS Version 2.0 for Windows

\begin{tabular}{|l|c|c|}
\hline \multicolumn{1}{|c|}{ Constructs } & Number of items & Cronbach's Alpha \\
\hline IT support & 4 & 0.728 \\
\hline Management support & 5 & 0.901 \\
\hline Intention towards paperless & 7 & 0.953 \\
\hline
\end{tabular}

The reliability of the above constructs are contributed by the respondents' answers who mainly have been in service between five to ten years as depicted in Table 2. This indicates that most of the university staff are seniors who are sincerely willing to share their perceptions of the IT support, management support and their intention towards paperless. With regards to the respondents with higher academic qualifications, Diploma levels and below have high percentage, $80 \%$ which testifies that diploma holders are eager to participate in the pilot survey compared to others. It is found that they have been recruited not only for the highest position in group B (e.g., Assistant Administrative Officer, Technical Assistant and Executive Officer) but some of them have accepted the position in group C (Clerical levels). Most of the staff in the survey is permanently working at a university and analysis shows that the majority (80\%) of the respondents have ICT experience at medium level. 
INTERNATIONAL JOURNAL OF ACADEMIC RESEARCH IN BUSINESS AND SOCIAL SCIENCES Vol. 8, No. 6, June 2018, E-ISSN: 2222-6990 @ 2018 HRMARS

Table 2. Demography of Respondents $(N=20)$

\begin{tabular}{|c|c|c|c|}
\hline No. & Items & Frequency & Percentage (\%) \\
\hline 1 & $\begin{array}{l}\text { Gender } \\
\text { - Male } \\
\text { - Female }\end{array}$ & $\begin{array}{l}10 \\
10\end{array}$ & $\begin{array}{l}50.0 \\
50.0\end{array}$ \\
\hline 2 & $\begin{array}{r}\text { Higher Academic Qualification } \\
\text { - Doctorate } \\
\text { - Master Degree } \\
\text { - Bachelor Degree } \\
\text { - Diploma } \\
\text { - Others }\end{array}$ & $\begin{array}{c}1 \\
1 \\
2 \\
10 \\
6\end{array}$ & $\begin{array}{c}5.0 \\
5.0 \\
10.0 \\
50.0 \\
30.0\end{array}$ \\
\hline 3 & $\begin{array}{r}\text { Department } \\
\text { - Faculty } \\
\text { - Non-Faculty/ Other } \\
\text { Departments }\end{array}$ & $\begin{array}{c}3 \\
17\end{array}$ & $\begin{array}{c}15.0 \\
85\end{array}$ \\
\hline 4 & $\begin{array}{r}\text { - In Group A } \\
\text { - In Group B } \\
\text { - In Group C } \\
\text { - Others }\end{array}$ & $\begin{array}{c}4 \\
11 \\
5 \\
0\end{array}$ & $\begin{array}{c}20.0 \\
55.0 \\
25.0 \\
0\end{array}$ \\
\hline 5 & $\begin{array}{l}\text { Status of Appointment } \\
\qquad \begin{aligned} \text { - Contract } \\
\text { - Permanent } \\
\text { - Temporary }\end{aligned}\end{array}$ & $\begin{array}{c}6 \\
13 \\
1\end{array}$ & $\begin{array}{c}30.0 \\
65.0 \\
5.0\end{array}$ \\
\hline 6 & $\begin{array}{r}\text { Year of Service } \\
\qquad \begin{array}{r}- \text { Less than } 5 \text { years } \\
-5-10 \text { years } \\
\text { - More than } 10 \text { years }\end{array}\end{array}$ & $\begin{array}{c}6 \\
11 \\
3\end{array}$ & $\begin{array}{l}30.0 \\
55.0 \\
15.0\end{array}$ \\
\hline 7 & $\begin{array}{l}\text { Information Communication } \\
\text { Knowledge } \\
\text { - High } \\
\\
\end{array}$ & $\begin{array}{c}3 \\
16 \\
1\end{array}$ & $\begin{array}{c}15.0 \\
80.0 \\
5.0 \\
\end{array}$ \\
\hline
\end{tabular}

\section{Conclusion}

In disclosing the "go green" motto through the e-government agenda in a highly challenging work environment of UAs, the participation of UAs staff become the main determinant especially when they have awareness and intention to take the necessary actions such as paperless based activities. In particular, the intention towards paperless should be strategically exist between the UAs staff through their strong belief on the benefits and advantages of practicing paperless. This must be actively promoted, and it is found that IT support and management support have received significant attention as important predictors in influencing intention towards paperless. One of the main roles 
INTERNATIONAL JOURNAL OF ACADEMIC RESEARCH IN BUSINESS AND SOCIAL SCIENCES

Vol. 8, No. 6, June 2018, E-ISSN: 2222-6990 @ 2018 HRMARS

of IT support and management support is to lead the use of technology and further, foster the intention towards paperless among the staff.

The main objective of this study is to conduct a pilot test. This study employed a Likert scale data during the pilot study. The evaluations of content and face validity as well as the reliability of the instrument become the main activities to ensure the actual survey can be proceeded. In content and face validity process, this study seeks for the acceptance of specialist views to get the most acceptable version of the instrument. Moreover, the reliability test found that all the items were reliable by having high values of Cronbach's Alpha that were above the benchmark of 0.70 . Showing that all items are acceptable and free of deletion for the actual survey.

\section{Acknowledgement}

A valuable appreciation to co-researchers/ co-authors who have mutually initiated their contributions for completing this study as well as preparing and submitting this manuscript to the journal successfully. Moreover, highly thank you to the Research and Innovation Management Centre, National Defence University of Malaysia in providing the Short-Grant Research 2016 for this study.

\section{Corresponding Author}

Mohd Hamran Mohamad, Faculty of Defence Studies and Management, Universiti Pertahanan Nasional Malaysia, Sungai Besi Camp, 57000 Kuala Lumpur, Malaysia. E-mail: hamran@upnm.edu.my. Tel: +6019-9142393

\section{References}

Al-Khouri, A. M. (2013). Environmental sustainability in the age of digital revolution: A review of the field. American Journal of Humanities and Social Sciences, 1, 202-211.

Anna, A. C. A., \& Yusniza, C. K. (2010). Adoption of tax e-filing. A conceptual paper. African Journal of Business Management, 4(5), 599-603.

Arzmi, A. B., \& Mohd Yahya, M. A. (2013). The usage of e-journal amongst lecturers at a public university in Malaysia. The Turkish Online Journal of Educational Technology, 12(2), 321-329.

Azman, A. (2012). E-government. Sabah: The Malaysian Administrative Modernization and Management Planning Unit (MAMPU).

Barker, S., Fiedler, B. \& Johnson, P. (2008). Paperless assignments: Moving forward or marking time? In Hello! Where are you in the landscape of educational technology? Proceedings ASCILITE Melbourne $2008 . \quad$ Retrieve from: http://www.ascilite.org.au/conferences/melbourne08/procs/barker.pdf.

Brusco, J. (2011). Trending toward paperless. AORN Journal, 94(1), 13-18.

Cavana, R., Delahaye, B. L., \& Sekaran, U. (2001). Applied Business Research: Qualitative and Quantitative Methods. Singapore: Markono Print Media Ltd.

Churchill, G. A., \& Peter, J. P. (1984). Research design effects on the reliability of rating scales: A metaanalysis. Journal of Marketing Research, 21(4): 360-375.

Davis, F. D. (1989). Perceived usefulness, perceived ease of use, and user acceptance of information technology. MIS Quarterly, 13(3), 319-340. 
INTERNATIONAL JOURNAL OF ACADEMIC RESEARCH IN BUSINESS AND SOCIAL SCIENCES

Vol. 8, No. 6, June 2018, E-ISSN: 2222-6990 @ 2018 HRMARS

Dawes, J. (2008). Do data characteristics change according to the number of scale points used? An experiment using 5-point, 7-point and 10-point scales. International Journal of Market Research, 50(1), 61-77.

Fishbein, M., \& Ajzen, I. (1975). Belief, attitude, intention, and behavior: An introduction to theory and research. Reading, MA: Addison-Wesley.

Gorondustse, A. H., \& Haim, H. (2013). Trust business social responsibility (BSR) on organizational performances in Nigerian small-scale industry: A pilot test. International Journal of Management Research and Review, 3(4), 2733-2739.

Government of Malaysia. (2011): The public-sector ICT strategic plan of Malaysia 2011- 2015. Retrieved from: www.mampu.gov.my. On 10 January 2017.

Hair, J. F., Black, W. C., Babin, B.J., \& Andersen, R.E. (2013). Mutilvariate data analysis. (7th ed.). Upper Saddle River, NJ: Pearson Education Ltd.

Krosnick, J. A., \& Fabrigar, L. R. (1997). Designing rating scales for effective measurement in surveys. In L. Lyberg, P. Biemer, M. Collins, E. De Leeuw, C. Dippo, N. Schwarz \& D.Trewin (Eds.), Survey measurement and process quality. New York: John Wiley \& Sons, Inc,

Malhotra, N. K. (2010). Essentials of marketing: An applied orientation. (6th ed.). Australia: Pearson Education.

Manuel, L. A. J., Jesus, H. M., Maria, Y. C. C. \& Francisco, J. A. P. (2013). An approach to the implementation of sustainability practices in Spanish universities. Journal of Cleaner Production, 1-11.

Miller, C. D., \& Salkind, J. N. (2002). Handbook of research design and social measurement. Thousand Oaks CA: SAGE.

Mouritsen, J., Larsen, H. T., Bukh, P. N. D. (2001). Intellectual capital and the 'capable' firm: narrating, visualizing and numbering for managing knowledge. Accounting, Organizations and Society, 26, 735-762.

Nunally, J. C. (2010). Psychometric theory. New York: Tata McGraw-Hill Education

Obeidat, M. A. Q. (2015). Empirical analysis for the factors affecting realization of paperless office. International Journal of Economics, Commerce and Management, 3(6), 773-792.

Quinn, R. E. (1988). Beyond rational management. San Francisco, CA: Jossey-Bass.

Rogers, D. P. (1987). The development of a measure of perceived communication openness. The Journal of Business Communication, 24(4): 53-61.

Saliza, A. A., \& Kamil, I. (2012). E-Government Application: The Challenges in Malaysia. Proceedings of World Business and Economics Research Conference 2012, Auckland, New Zealand. Retrieved from SSRN: http://ssrn.com/abstract=2184632 or http://dx.doi.org/10.2139/ssrn.2184632.

Sekaran, U., \& Bougie, R. (2016). Research methods for business: A skill building approaches (7th ed.). Chichester: John Willey \& Sons Ltd.

Venkatesh, V. (2000). Determinants of perceived ease of use: integrating control, intrinsic motivation, and emotion into the technology acceptance model. Information Systems Research, 11(4), 342365.

Venkatesh, V., \& Davis, F. D. (2000). A theoretical extension of the technology acceptance model: Four longitudinal field studies. Management Science, 46(2), 186-204.

Young, B. L. (2017). Exploring the relationship between e-government development and environmental sustainability. A study of small island developing states. Sustainability, 9(5), 732. 
INTERNATIONAL JOURNAL OF ACADEMIC RESEARCH IN BUSINESS AND SOCIAL SCIENCES

Vol. 8, No. 6, June 2018, E-ISSN: 2222-6990 @ 2018 HRMARS

Zainudin, H. A. (2010). Research methodology for business and social sciences. Universiti Teknologi MARA, Shah Alam: University Publication Centre (UPENA). 